\title{
Mechanisms regulating follicular development and selection of the dominant follicle
}

\author{
R. Webb ${ }^{1}$, B. Nicholas ${ }^{1}$, J. G. Gong ${ }^{2}$, B. K. Campbell ${ }^{3}$, \\ C. G. Gutierrez ${ }^{4}$, H. A. Garverick ${ }^{5}$ and D. G. Armstrong ${ }^{2}$
}

${ }^{3}$ Division of Agricultural Sciences, School of Biosciences, University of Nottingham, Loughborough LE12 5RD, UK; ${ }^{2}$ Division of Integrative Biology, Roslin Institute, Roslin, Midlothian EH25 9PS, UK; ${ }^{3}$ Department of Obstetrics and Gynaecology, School of Human Development, University of Nottingham, Nottingham NG7 $2 \mathrm{UH}, U K$; ${ }^{4}$ Facultad de Medicina Veterinaria, Universidad Nacional Autonoma de Mexico, DF 0451 Mexico; and ${ }^{5}$ Department of Animal Sciences, University of Missouri, Columbia, MO 65211, USA

Reproductive function is an integrated process encompassing both extraovarian signals, such as gonadotrophins, and intrafollicular factors, such as locally produced growth factors. Initiation of primordial follicle growth and the early stages of folliculogenesis can occur without gonadotrophins. However, in vivo and in vitro studies indicate that FSH may stimulate the rate of preantral follicle growth and that it can take only 3 months for a primordial follicle to reach the ovulatory stage. Antral follicle development from 2 and $4 \mathrm{~mm}$ in diameter in sheep and cattle, respectively, is gonadotrophin dependent. During the oestrous cycle a transient increase in circulating FSH precedes the recruitment of a group of follicles. Recruited follicles are characterized by induction of expression of mRNAs encoding a range of steroidogenic enzymes, gonadotrophin receptors and local regulatory factors. As follicles continue to mature, there is a transfer of dependency from FSH to $\mathrm{LH}$, which may be part of the mechanism involved in selection of follicles for continued growth. The mechanism of selection of the ovulatory follicle seems to be linked to the timing of mRNA expression encoding $\mathrm{LHr}$ and $3 \beta$-hydroxysteroid dehydrogenase $(3 \beta-H S D)$ in granulosa cells. Locally produced growth factors, such as the insulin-like growth factors (IGFs) and members of the transforming growth factor $\beta$ (TGF $\beta$ ) superfamily (inhibins, activins and bone morphogenetic proteins (BMPs)), work in concert with gonadotrophins throughout the follicular growth continuum. The roles of growth factors in follicular development and survival are dependent on gonadotrophin status and differentiation state, including morphology. In conclusion, it is the integration of extraovarian signals and intrafollicular factors that determine whether a follicle will continue to develop or be diverted into atretic pathways, as is the case for most of the follicles in monovulatory species, such as cattle. 


\section{Introduction}

As soon as the primordial follicle store has been established, usually during fetal development in ruminants (Juengel et al., 2002), follicles begin to grow. Once initiated, growth continues without halting until the follicle either becomes atretic or proceeds to ovulation. In monovulatory species like cattle, only a few follicles from the original store of follicles $(<0.1 \%)$ will ovulate. The mechanisms that are involved in either the initiation of follicle growth or the number of primordial follicles that start to grow each day are still not known. Ovarian autograft studies have confirmed earlier histological estimates that it takes several months for a primordial follicle to reach the Graafian stage (Gosden et al., 1994; Baird et al., 1999; Campbell et al., 2000). This is a relatively long period when various perturbations, including environmental factors such as nutrition, can influence follicular development and oocyte quality and, hence, fertility (Webb et al., 1999a,b). This review will discuss the key stages of follicular development, mainly in cattle. Emphasis will focus particularly on the interaction between gonadotrophins and intrafollicular factors.

\section{Preantral follicle development}

Primordial follicles consist of an oocyte surrounded by approximately 24 flattened or cuboidal granulosa cells (McNatty et al., 1999). Growth of primordial follicles is most likely dependent upon the presence of oocyte-granulosa cell interactions, such as C-kit-kit ligand interactions and the secretion of a range of factors, including members of the transforming growth factor $\beta$ (TGF $\beta$ ) superfamily, for example growth differentiating factor 9 (GDF-9), activins, inhibins and other factors, such as basic fibroblast growth factor (bFGF) and epidermal growth factor (EGF) (McNatty ef al., 1999; Knight and Glister, 2001; Smitz and Cortvindt, 2002).

Mechanisms regulating activation from the resting primordial pool of follicles and subsequent growth of primordial follicles still remain poorly understood; however, follicle growth can be divided into two distinct phases (Braw-Tal and Yossefi, 1997). The first phase involves the transition of the granulosa cells surrounding the oocyte from a phenotype consisting of a mixture of flattened and cuboidal shapes (type 1 and 1a follicles) to a cuboidal proliferating phenotype (type 2 follicles). The second phase is characterized by granulosa cell proliferation and a rapid increase in the size of the oocyte. In cattle, the critical point for the initiation of oocyte growth was estimated to occur in follicles containing approximately 40 granulosa cells (McNatty et al., 1999). Soon after formation of the theca interna, mRNAs for the steroidogenic enzymes, cytochrome $\mathrm{P} 450$ side chain cleavage (P450scc), cytochrome

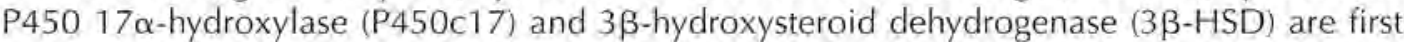
expressed. Cytochrome P450 aromatase (P450arom) is localized solely to granulosa cells (Bao and Garverick, 1998) and is detected later in antral follicles; however, preantral follicles appear to be capable of producing oestradiol early in development (Thomas et al., 2001; K. J. Dugan, M. Lopez-Bejar, D. G. Armstrong and R. Webb, unpublished).

\section{Role of gonadotrophins}

Gonadotrophins are probably not involved in the initiation of follicle growth (Campbell et al., 2000; Fortune et al., 2000), although previous studies investigating gene expression in preantral follicles have demonstrated that $\mathrm{FSH}$ receptor ( $\mathrm{FSHr}$ ) $\mathrm{mRNA}$ can be detected in follicles with only one or two layers of cells (Bao and Garverick, 1998). Later in preantral 


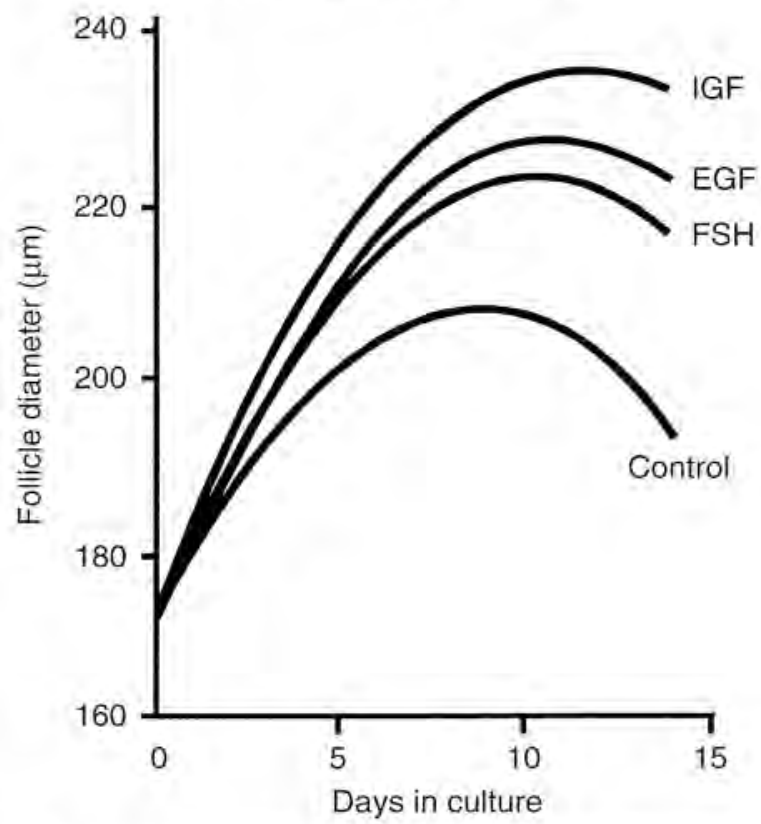

Fig. 1. Effect of FSH $\left(1 \mathrm{ng} \mathrm{ml}^{-1}\right)$ and growth factors (long-R3, insulin-like growth factor I (LR3-IGF-I, $1 \mathrm{ng}$ $\mathrm{ml}^{-1}$ ) and epidermal growth factor (EGF, $0.5 \mathrm{ng} \mathrm{ml}^{-1}$ ) on the growth of bovine preantral follicles in a long-term serum free culture system (up to 15 days). Treatment with both FSH and growth factors significantly enhanced $(P<0.05)$ growth rate when compared with controls. (Adapted from Gutierrez et al,$+ 2000_{+}$)

follicle development, both in vivo (Campbell et al., 2000) and in vitro (Gutierrez et al., 2000) studies have demonstrated that FSH can accelerate the rate of preantral follicle development (Fig. 1). In this in vitro system, bovine preantral follicles were sustained in long-term culture, developed an antrum and were responsive to the stimulatory effects of FSH. In summary, the results indicate that FSH may influence early follicle growth.

Expression of $\mathrm{LH}$ receptor $(\mathrm{LHr}) \mathrm{mRNA}$ is localized to thecal cells during the preantral and early antral stages of growth, and is detected first when the theca interna forms around the granulosa cells. Presumably LH is required for the stimulation of androgen precursors for oestrogen production in preantral follicles.

\section{Locally produced factors}

Although further work is required to clarify the role of gonadotrophins at these early stages of follicle development, recent work has indicated that locally produced factors have important roles. In the long-term culture system of Gutierrez et al. (2000), IGF-I, as well as EGF, stimulated follicular growth (Fig. 1). The importance of IGFs in regulating ovarian function has been confirmed by gene knock-out experiments in mice in which there was impaired folliculogenesis before the antral stage of development (Elvin and Matzuk, 1998). However, the precise interpretation of such results is complicated by functional redundancy 


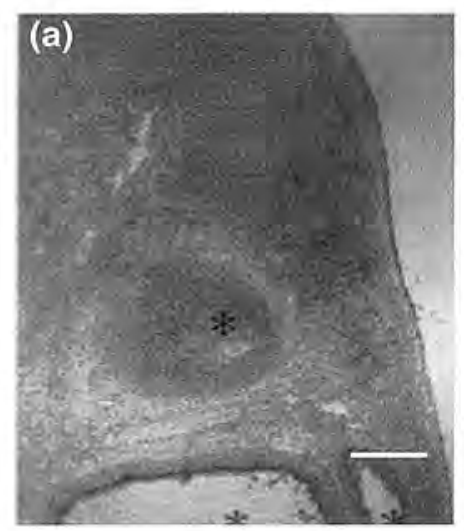

(d)
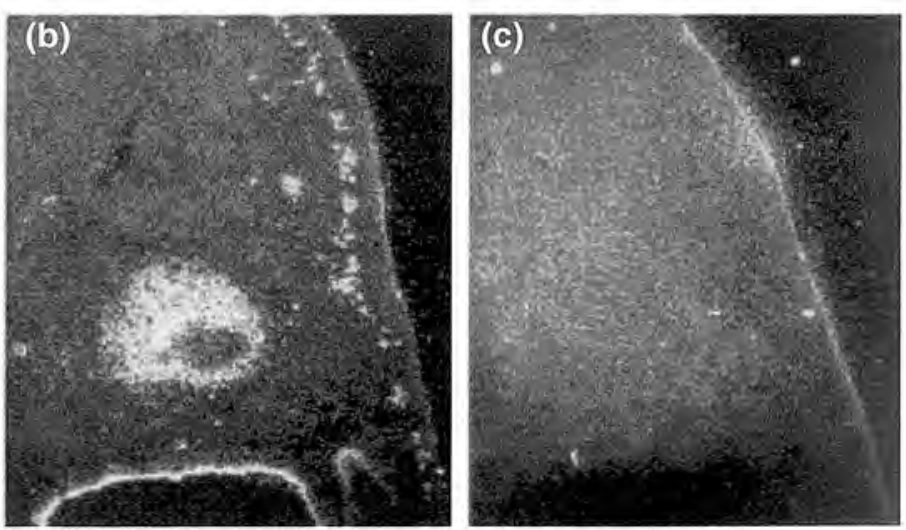

(e)

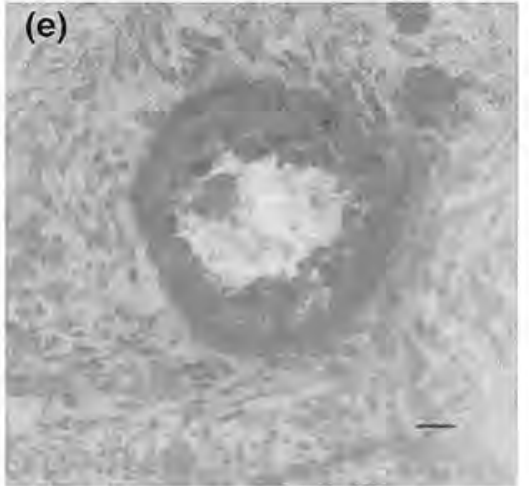

Fig. 2. (a) Light field and (b,c) dark field illumination of cryopreserved sections of bovine ovarian tissue showing expression of insulin-like growth factor binding protein 2 (IGFBP-2) in preantral follicles. A string of preantral follicles containing silver grains is observed in the ovarian cortex under (b) dark field illumination. Sections of bovine ovary were incubated with (d) normal rabbit serum or (e) an antibody raised against bovine recombinant IGFBP-2, and showed localization within the granulosa cell layer of preantral follicles. (a) Asterisk denotes an antral follicle. Scale bars represent (a) $400 \mu \mathrm{m}$ and (e) $25 \mu \mathrm{m}$. Adapted from Armstrong et al. (2002).

within the IGF system and caution should be exercised when extrapolating results obtained in mice to other species because of differences in their follicular IGF system. In this regard it has been shown that even between two closely related species, such as rats and mice, there are significant differences in the spatial patterns of expression of IGFBP-2 and -4 (Adashi et al., 1997).

Armstrong et al. (2002) demonstrated that bovine granulosa cells of preantral follicles express mRNAs encoding IGFBP-2 (Fig. 2) and type 1 IGF receptor. Unlike pig granulosa cells that express mRNA encoding IGFBP-3 (Wandji et al., 2000), bovine granulosa cells do not express IGFBP-3 (Armstrong et al., 2002). However, the theca externa of antral follicles and the stromal tissue surrounding preantral follicles was shown to be a site of IGFBP-3 mRNA expression. These results are in agreement with an earlier study (Armstrong et al., 2000) in which it was demonstrated that IGF-I and -II mRNAs were not expressed in granulosa cells of preantral or antral follicles. It was hypothesized that IGFs regulate preantral follicle growth via endocrine mechanisms, supporting the notion that IGFBP- 2 and -3 regulate the bioavailability 


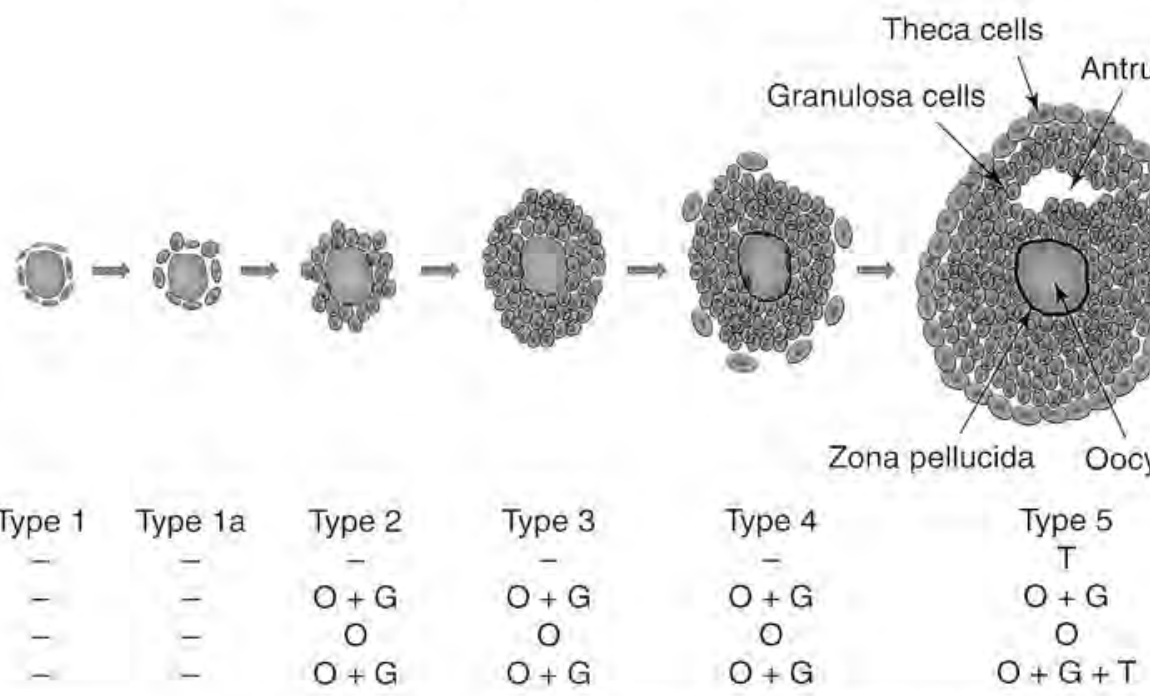

Fig. 3. Diagrammatic representation of the temporal changes in the expression of mRNA encoding components of the insulin-like growth factor (IGF) system in bovine follicles during different stages of growth (see Braw-Tal and Yossefi, 1997). IGFr: type 1 IGF receptor; O: oocyte; G: granulosa cells; T: theca cells, Asterisk denotes cases in which some preantral follicles did not contain IGFBP-2 mRNA expression. (Redrawn from Armstrong et al., 2002.)

of IGF-I (derived mainly from extraovarian sources) and -II (derived from adjacent antral follicles) during these early stages of follicle growth (Fig. 3),

Using the same culture system as Gutierrez et al. (2000), but for a shorter culture period and with tenfold higher concentrations of an IGF-I analogue, McCaffery et al. (2000) failed to show an effect of the IGF analogue on follicle growth, but did find a negative effect on oocyte size. These results support the view that IGFBPs have an important role in maintaining IGFs in an optimum range. Other attempts at the development of serum-free bovine culture systems that result in the activation and subsequent growth of primordial follicles have used explants of ovarian cortex (Braw-Tal and Yossefi, 1997; Fortune et al., 2000). In contrast to rodents, in which this system resulted in normal rates of primordial follicle activation, uncontrolled activation of bovine primordial follicles in bovine ovarian cortex resulted. The reasons for these differences are unknown. Although IGFs were not added to the medium used to support follicle development, a supra-physiological concentration of insulin was used, which has the potential to act via the type 1 IGF receptor. As preantral follicles express both IGFBP-2 and -3 (Armstrong et $\mathrm{al}_{+}, 2002$; Fig. 2), which bind IGFs and so limit their access to the type 1 receptor, the use of high concentrations of insulin in vitro could bypass mechanisms that regulate activation of the type 1 IGF receptor in vivo.

The spatial and temporal patterns of expression of the components of the IGF system during early stages of bovine follicular growth are summarized (Fig. 3). Current results indicate that, unlike some growth factors, the IGF system is not involved in initiation of primordial follicle growth, but is involved in subsequent events.

Other growth factors undoubtedly have a role (McNatty et al., 1999), as a significant effect of BMP treatment on oestradiol production by preantral follicles in culture has recently been found (K. J. Dugan, M. Lopez-Bejar, D. G. Armstrong and R. Webb, unpublished). Interestingly, the responses among three different BMPs (BMP-2, -4 and -6 ) were similar, as also appears 
to be the case in larger follicles (Glister et al., 2002), indicating functional redundancy as indicated for the IGF system.

\section{Early follicle growth and recruitment}

Bovine oestrous cycles are characterized by two or three waves of follicular growth (Adams, 1999) and each wave of growth is characterized by recruitment of approximately three to five follicles that grow to $>4 \mathrm{~mm}$ in diameter. This group of recruited follicles continues growth until follicles reach approximately $6-8 \mathrm{~mm}$ in diameter, whereby one is selected for continued growth and becomes dominant over the others.

\section{Role of gonadotrophins}

Initiation of follicular recruitment in cattle is under the control of FSH secretion. Emergence of each wave of follicular growth is preceded by a transient increase in FSH secretion that lasts for 1-2 days (Adams, 1999). It is likely that FSH can stimulate growth of follicles $<2 \mathrm{~mm}$ in diameter, based on the observation that treatment of hypogonadotrophic cattle with bovine follicular fluid and oestradiol, which further reduces FSH concentrations, severely restricts follicular development (Campbell et al., 2003).

As reviewed (Bao and Garverick, 1998; Webb et al., 1999a), localization and quantification of the mRNAs for the gonadotrophic receptors (FSHr and $\mathrm{LHr}$ ) and key steroidogenic cytochrome P450 enzymes, including P450scc, P450c17 and P450arom, and 3B-HSD have been investigated. It was found that only mRNA expression of the $\mathrm{FSH}$ receptor was detectable in granulosa cells of non-recruited follicles that were $\leqslant 4.5 \mathrm{~mm}$ in diameter. Expression of mRNA for the LHr, P450scc, P450c17 and 3 3 -HSD has been detected in theca cells of non-recruited follicles. Growth of follicles to $\geqslant 5 \mathrm{~mm}$ in diameter was characterized by induction of mRNA expression of P450scc and P450arom in granulosa cells and by an increase in mRNA of the gonadotrophin receptors and steroidogenic enzymes with increasing follicular size. These data are consistent with a report by Skyer et al. (1987) whereby only follicles that were $>5 \mathrm{~mm}$ in diameter produced significant amounts of oestradiol in follicular fluid.

The role of FSH in follicular growth and mRNA expression for P450scc and P450arom has been determined (Garverick et al., 2002) using a GnRH agonist (GnRHa) osmotic minipump model (Gong et al., 1995, 1996a) in which pituitary gonadotrophin secretion was significantly reduced over 6 weeks. Follicular growth was inhibited to approximately $4 \mathrm{~mm}$ in diameter. Thereafter, physiological concentrations of FSH were infused for $48 \mathrm{~h}$ into the GnRH-treated heifers. Circulating FSH concentrations were similar to those observed in control heifers at the peak of the transient increase in FSH that precedes emergence of a follicular wave during a normal oestrous cycle. The FSH treatment stimulated growth of follicles $\geqslant 8.5 \mathrm{~mm}$ in diameter by the end of the infusion period. Increased mRNA expression for P450scc and P450arom was also induced (Fig. 4). Expression of mRNA for P450scc and P450arom in granulosa cells and for P450c17 in theca was higher in recruited follicles of FSH infused cows in the GnRHatreated group than in recruited follicles of similar size in cows with normal oestrous cycles. These results demonstrate the key role that FSH plays in the induction of follicular growth and differentiation. Furthermore, the infusion of FSH into the GnRHa-treated cows (Garverick et al., 2002) induced mRNA expression of P450scc and P450arom in granulosa cells in smaller sized follicles than occurs in control cows. Interestingly, this may be comparable to the situation in sheep carrying the major $F e c B$ gene, which increases ovulation rate and causes precocious follicular differentiation (Souza et al., this issue; McNatty et al., this issue; 

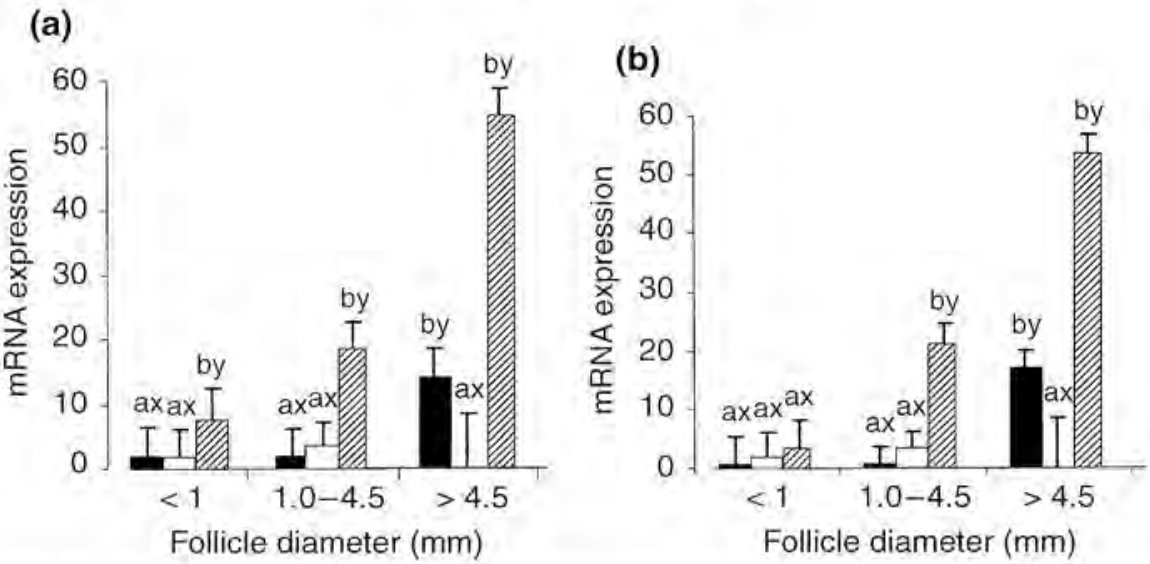

Fig. 4. Expression of (a) cytochrome P450 side-chain cleavage (P450scc) and (b) cytochrome $P 450$ aromatase ( $P 450$ arom) mRNAs (mean \pm SEM) in granulosa cells in bovine follicles collected on day 2 of the first follicular wave (control, $\mathbf{a}$ ) and after GnRH agonist $(\mathrm{GnRHa}, \mathrm{G})$ treatment alone and GnRHa with FSH treatment $(\mathrm{GnRHa}+\mathrm{FSH}, \mathbf{z})$. The intensity of hybridization is quantified as the percentage of pixels within the given marked area occupied by silver grains. ${ }^{\text {a.b }}$ Significant differences among treatments within days, ${ }^{x}$ "Significant differences between days within treatment group, $n=5$ animals per treatment group. (Adapted from Garverick et al., 2002.)

Mulsant et al., this issue). This finding is due to a mutation in the BMP-1B receptor. The presence of the $F e c B$ mutation increases the expression of mRNA for P450arom and inhibin $\beta A$ subunit in granulosa cells (Webb et al, 1999a). It remains to be determined whether FSH treatment in cattle alters follicular maturation via changes in follicular BMP related factors.

\section{Locally produced factors}

The early antral stage of follicle development is critical because follicles are dependent upon the presence of FSH for their survival. However, locally produced factors also appear to have a role, as IGFs are thought to enhance the effect of FSH (Webb et al., 1999b). It is about the time of antrum formation that IGF-II mRNA was first detected in thecal tissue. Type 1 IGF receptor and a range of IGFBPs (IGFBP-2, -3 and -4) are also detected at this stage of development (Armstrong et al., 1998, 2000). In situ hybridization data failed to detect the presence of IGF-I mRNA in granulosa tissue at any stage of development (Armstrong et al., 1998, 2000). These data support the results of Perks et al. $(1995,1999)$ in sheep and cattle, but not those of Leeuwenberg et al., (1995) in sheep and Yuan et al. (1998) in cattle, who have demonstrated the presence of mRNA encoding IGF-I in granulosa cells from both subordinate and dominant follicles. Previous work using bovine granulosa cell cultures (Spicer et al., 1993; Spicer and Echternkamp 1995) also detected IGF-I mRNA. The differences in IGF-I mRNA expression patterns that have been reported by different laboratories have been explained by differences in the sensitivity of probes used in the different studies. However, in this case the IGF-I probe used in the studies of Armstrong et al. $(1998,2000)$ and that described by Yuan et al. (1998) was the same. Nevertheless, despite the differences in abundance of IGF-I mRNA 
detected between laboratories, the results of Yuan et al. (1998) also show that IGF-II mRNA expression is significantly greater than that of IGF-I and support the conclusion that IGF-II is the major intrafollicular IGF ligand regulating the growth of bovine antral follicles (Armstrong et al., 1998, 2000; Webb et al., 1999a).

A number of other local growth factors, including members of the TGF $\beta$ superfamily, are also present in early antral follicles. These factors include the BMPs (BMP-15, BMPR2) and their receptors (BMPR1A and BMPR1B), $\alpha$ inhibin, and $\beta A$ inhibin and TGF- $\beta 1,-\beta 2$ and $-\beta 3$. The precise roles of these different factors are not known, but similar to the IGF system, it is likely that they are involved in follicular differentiation by enhancing the action of gonadotrophins (Campbell and Baird, 2001; Knight and Glister, 2001; Montgomery et al., 2001; Souza et al., 2002).

\section{Follicle selection and dominance in cattle}

In monovulatory species such as cattle, the mechanism whereby only one dominant follicle from the cohort of follicles recruited at the beginning of a follicular wave continues to develop, whereas the others regress, is of central importance. Although the recent application of transrectal ultrasonography has greatly increased our understanding of this process in terms of temporal associations between changes in follicle dynamics and peripheral hormone concentrations (Webb et al., 1999a; Fortune et al., 2001; Ginther et al., 2001), the precise mechanism of dominance remains to be fully elucidated.

\section{Role of gonadotrophins}

Circulating FSH concentrations start to decrease after the emergence of the follicular wave and remain low during the growing and early plateau phase of the dominant follicle (Adams, 1999; Fig. 5). It has been suggested that this decrease in FSH secretion may be a key mechanism underlying follicle selection. It has been shown that infusion of FSH can override the process of follicle selection (Mihm et al., 1997). All recruited follicles appear to contribute to the initial decline in circulating FSH (Gibbons et al., 1997), but the largest follicle has the major role in decreasing further the circulating FSH to concentrations below that required to support the continued growth of the cohort of smaller follicles (Webb et al., 1999a; Ginther et al., 2001). This decrease in circulating concentrations of FSH results in a rapid deviation in the size of the future dominant follicle and the largest subordinate follicle, which can be detected within an $8 \mathrm{~h}$ window when the future dominant follicle is approximately $8.0-8.5 \mathrm{~mm}$ in diameter (Kulick et al., 1999). The main factors produced by the growing and selected follicles that act in a negative feedback manner to suppress the secretion of FSH are oestradiol and inhibin (Webb et al., 1999a,b; Bleach et al., 2001). Oestradiol secretion is negatively related to FSH during the first follicular wave, but not later waves, and this may be due to the progesterone-mediated depression of $\mathrm{LH}$ secretion during the mid- to late luteal phase. Similarly, inhibin A secretion is inversely related to FSH during the first follicular wave, but the relationship is not as clear in later follicular waves (Webb et al, 1999a).

The relative importance of inhibin and oestradiol in controlling both FSH and follicular waves in cattle is still open to question. Passive or active oestradiol immunization (Webb and Morris, 1988) results in increased FSH, but also induces follicular cysts due to interference with positive feedback. Similarly, inhibin active immunization has not proved a very satisfactory experimental model as a result of the extreme variability of the response obtained, both 


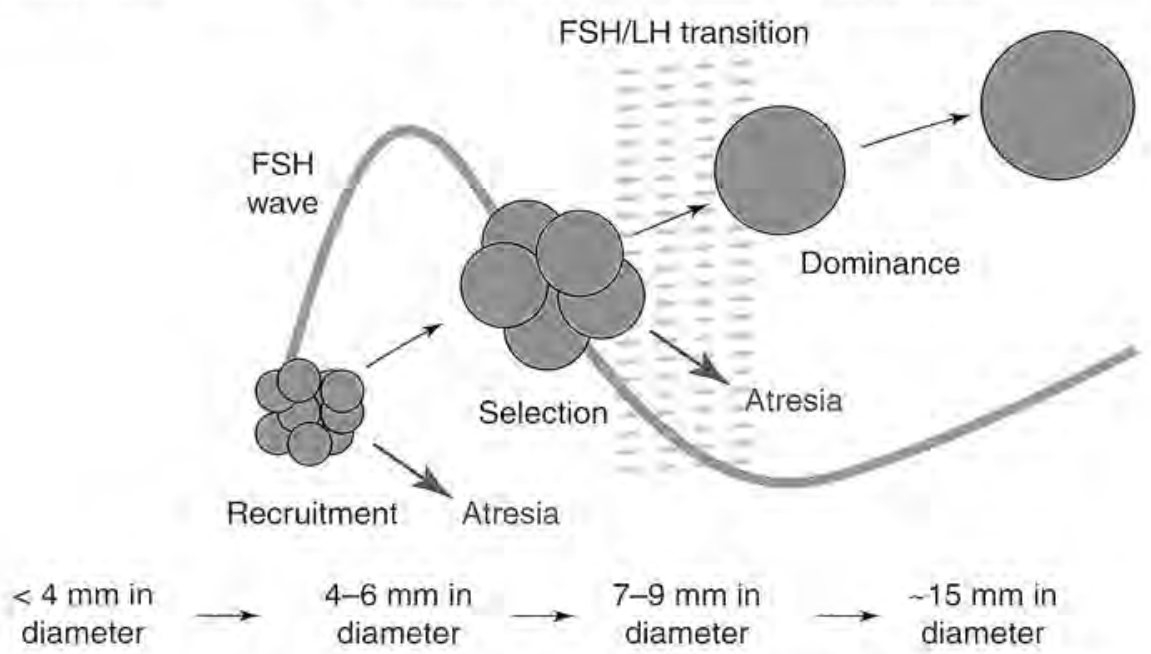

Fig. 5. Schematic representation of the requirement for gonadotrophins at different stages of ovarian follicle development in cattle.

between and within animals across successive oestrous cycles. Studies using passive inhibin immunization in sheep with ovarian autotransplants have shown complete deregulation of selection mechanisms during both the early (Campbell et al., 1995) and late (Campbell and Scaramuzzi, 1995) luteal phase, in response to a sustained increase in FSH when antiserum is given as an acute bolus followed by supplementary daily injections. A similar protocol was applied to a group of cyclic heifers in which the initial bolus of antiserum was injected on day 2 of the oestrous cycle, and supplementary injections were given on days 3-8. Luteal regression was induced on day 7 by injection with prostaglandin and the pattern of follicle development and ovulation followed by transrectal ultrasonography. All control and treated animals had single ovulations in the oestrous cycle before immunization. After treatment, all immunized animals developed two or three dominant follicles during the first follicular wave and six of seven animals responded to prostaglandin and ovulated. All treated animals that ovulated had twin ovulations with two of six unilateral and four of six bilateral, despite no significant effect of treatment on FSH concentrations (B. K. Campbell, J. G. Gong and $R$. Webb, unpublished). These results demonstrate that inhibin is a vital component of the feedback systems regulating follicular recruitment and selection. The lack of measurable change in $\mathrm{FSH}$ in twin ovulating heifers after passive inhibin immunization probably reflects the sensitivity of this feedback system, although direct effects on the ovary cannot be discounted. During the process of follicle selection, FSH is still required by the selected follicle, as a decrease in FSH to below the basal values inhibited the further growth of the largest follicle.

It is intriguing that the selected follicle continues further development in an environment of a declining FSH concentration that is not adequate to support the growth of subordinate follicles. It has been suggested that the future dominant follicle maintains a size advantage over its cohorts from the point of recruitment and, therefore, develops mechanisms that enable it to use the lower FSH concentrations before the cohort of follicles have acquired a similar ability (Ginther et al., 2000). These mechanisms include the production of substances by 
Table 1. Qvarian responses of GnRHa-treated heifers to different regimens of FSH-L,H infusion at physiological concentrations

\begin{tabular}{|c|c|c|c|c|c|c|}
\hline & $\begin{array}{l}\text { Group } j^{\text {a }} \\
(n=6)\end{array}$ & $\begin{array}{l}\text { Group } 2^{b} \\
(n=6)\end{array}$ & $\begin{array}{l}\text { Group } 3^{c} \\
(n=6)\end{array}$ & $\begin{array}{l}\text { Group } 4^{\mathrm{d}} \\
(n=6)\end{array}$ & $\begin{array}{l}\text { Group } 5^{e} \\
(n=6)\end{array}$ & $\begin{array}{l}\text { Group } 6^{\prime} \\
(n=6)\end{array}$ \\
\hline $\begin{array}{l}\text { Follicle recruitment } \\
\text { within } 24 \mathrm{~h}\end{array}$ & + & + & + & + & + & + \\
\hline $\begin{array}{l}\text { Continued growth after the } \\
\text { end of FSH infusion }\end{array}$ & $N / A$ & - & $\mp$ & + & + & + \\
\hline $\begin{array}{l}\text { Follicles }>13 \mathrm{~mm} \text { in diameter } \\
\text { by day } 6 \text { of infusion }\end{array}$ & + & - & + & + & + & + \\
\hline $\begin{array}{l}\text { Number of follicles }>10 \mathrm{~mm} \\
\text { in diameter }\end{array}$ & $12.5 \pm 1.4$ & 0 & $10.9 \pm 2.2$ & $12.2 \pm 1.9$ & $14.1 \pm 2.3$ & $1.0 \pm 0.3^{*}$ \\
\hline $\begin{array}{c}\text { Number of animals that } \\
\text { ovulated after hCG }\end{array}$ & 6 & 0 & 1 & 5 & 6 & 5 \\
\hline $\begin{array}{l}\text { Total number of corpora } \\
\text { lutea }\end{array}$ & 37 & 0 & 2 & 23 & 21 & 5 \\
\hline
\end{tabular}

Animals were treated with GnRHa $\left(2.5 \mu \mathrm{g} \mathrm{h}^{-1}\right)$ via osmotic minipumps for approximately 6 weeks to arrest follicle growth at approximately $4 \mathrm{~mm}$ in diameter. $\mathrm{FSH}-\mathrm{LH}$ was then infused as detailed below via jugular canulae and 2500 iu hCG was given i.m. at the end of infusion.

${ }^{a}$ Continuous FSH $\left(50 \mu \mathrm{g} \mathrm{h}^{-1}\right)$ infusion for 7 days; ${ }^{b}$ continuous FSH $\left(50 \mu \mathrm{g} \mathrm{h}^{-1}\right)$ infusion terminated when at least one follicle had reached $8-9 \mathrm{~mm}$ in diameter, ${ }^{\mathrm{C}} \mathrm{FSH}$ as for group 2, with LH (25 $\mu \mathrm{g}$ per pulse) given at $4 \mathrm{~h}$ intervals for 7 days; ${ }^{\mathrm{d}} \mathrm{FSH}$ as for group 2, with $\mathrm{LH}$ ( $25 \mu \mathrm{g}$ per pulse) given at $1 \mathrm{~h}$ intervals for 7 days; eFSH as for group 2, with LH $(25 \mu \mathrm{g}$ per pulse) given at $4 \mathrm{~h}$ intervals during FSH infusion then at $3 \mathrm{~h}$ intervals for $24 \mathrm{~h}$, at $2 \mathrm{~h}$ intervals for $24 \mathrm{~h}$ and at $1 \mathrm{~h}$ intervals for $48 \mathrm{~h}$; 'as for group 5 , but FSH was terminated when recruited follicles had reached $6-7 \mathrm{~mm}$ in diameler.

*The number for six individuals was $0,1,1,1,1,2$.

the future dominant follicle, such as oestradiol and various locally produced growth factors and proteins that can increase its sensitivity to FSH and/or inhibit directly the growth of subordinate follicles.

The deviation in diameter between the two largest follicles is also associated with a transient increase in peripheral LH concentrations (Kulick et al., 1999), but whether LH is actively involved in follicle selection remains uncertain. Very soon after the morphological selection of the dominant follicle (at about $9 \mathrm{~mm}$ in diameter), $\mathrm{LHr}$ and $3 \beta$-HSD mRNA start to be expressed in granulosa cells (Bao and Garverick, 1998; Webb et al., 1999a). This finding indicates that the dominant follicle can use LH to support its continued growth even when circulating FSH concentrations are declining. This view is supported further by the observation that the lifespan of the dominant follicle can be extended with optimum pulsatile LH support (Fortune, 1994). Furthermore, similar results have been obtained from studies in GnRHantagonist suppressed sheep (Campbell et al., 2000).

A hypogonadotrophic (GnRHa) model was used in conjunction with FSH and/or $\mathrm{LH}$ infusion to investigate in detail the role of $\mathrm{FSH}$ and $\mathrm{LH}$ in follicle selection and dominance in cattle. We found that FSH alone, or in combination with $\mathrm{LH}$, at physiological concentrations stimulated follicles of $<4 \mathrm{~mm}$ in diameter to develop to the preovulatory stages and these preovulatory follicles were capable of ovulating in response to hCG (Table 1). In addition, large follicles ( $>9 \mathrm{~mm}$ in diameter) may be able to transfer their dependence from FSH to $\mathrm{LH}$, and adequate $\mathrm{LH}$ pulsatile support appears to be required to maintain the ovulatory competence of the preovulatory follicles under decreased FSH concentrations (Gong et al., 1996b). Furthermore, to mimic the hormone patterns of the normal follicular phase, hypogonadotrophic heifers were infused with FSH in combination with low frequency LH pulses 
to recruit follicles, and were then given an increasing frequency of $\mathrm{LH}$ pulses to support further the development of the recruited follicles to preovulatory stages. The results (Table 1) demonstrate that the duration of the initial exposure to $\mathrm{FSH}$ is critical for normal follicle selection and dominance, as FSH infusion for $>48 \mathrm{~h}$ when the recruited follicles had reached a diameter of 6-7 mm always induced a superovulatory response. However, FSH exposure for approximately $48 \mathrm{~h}$ resulted in selection of one or two dominant follicles in most cases. These data are consistent with those generated using a parallel model in sheep (Campbell et al., 2000). Our current understanding of the role of declining FSH and subsequent LH support in follicle selection and dominance is summarized (Fig. 5).

\section{Locally produced factors}

The effects of gonadotrophins are almost certainly mediated in conjunction with local factors, demonstrating the importance of paracrine mechanisms. Development of serumfree culture systems (Campbell et al., 1995; Gutierrez et al., 1997), in which the follicular phenotype is maintained without significant luteinization, has proved invaluable for analysing the factors involved in the local regulation of ovarian function in ruminants. This culture system has been used to demonstrate that FSH can induce oestradiol production by bovine granulosa cells (Gutierrez et al., 1997; Nicholas et al., 2000) and that this induction is related to an increase in P450arom mRNA expression (Silva and Price, 2001). This culture system has been used to identify a wide range of local factors that are likely to be involved in the regulation of follicular growth, including members of the TGF $\beta$ superfamily, FGF and EGF/TGF $\alpha$ (Armstrong and Webb, 1997; Webb et al., 1999a,b).

For example, genes for all the components of the IGF system are expressed in large antral follicles. In cows, IGF-II gene expression is restricted to the thecal tissue of antral follicles (Armstrong et al., 2000), providing additional support that IGF-II is the major intraovarian IGF. However, IGF-I may still act in an endocrine manner and shows a positive correlation with follicle growth after recombinant growth hormone treatment (Webb et al., 1999a,b). It has been suggested that IGFBPs have a regulatory role in follicle development in cattle (Echternkamp etal, 1994). These workers and Austin etal. (2001) have observed that IGFBP-2, and possibly IGFBP-4 and -5, concentrations are higher in the follicular fluid of small and medium-sized follicles and follicular fluid of large artretic follicles, but are markedly reduced or undetectable in follicular fluid of large or dominant follicles (Nicholas et al., 2002). We have also shown that IGFBP-2 and -4 mRNA expression is restricted to granulosa and theca tissue, respectively, in healthy bovine antral follicles up to $9 \mathrm{~mm}$ in diameter (Armstrong et al., 1998). Furthermore, we were unable to detect IGFBP-2 mRNA expression in granulosa tissue from large dominant follicles, and recent data from our laboratory has indicated that FSH may be acting indirectly to inhibit IGFBP-2 expression ( $K_{+}$J. Woad, B. K. Campbell, H. A. Garverick, C. G. Gutierrez, J. G. Gong, G. Baxter, C. O. Hogg, R. Webb and D. A. Armstrong, unpublished). This finding indicates that low amounts of IGFBP-2 and an increase in the number of $\mathrm{LH}$ receptors in granulosa cells may be related to the establishment of the dominant follicle. A reduction in follicular fluid IGFBP-4 concentrations, coupled with an increase in oestradiol concentrations, has also been demonstrated in the dominant follicle in cattle (Mihm et al, 2000). Overall, these results indicate that the regulation of intrafollicular IGF bioavailability is a key factor controlling selection and maintenance of the dominant follicle in cattle.

Post-translational modifications of the IGFBPs are also known to occur and at least 51 isoforms of IGFBPs have been found in bovine follicular fluid (Nicholas et al., 2002) (Fig. 6). 


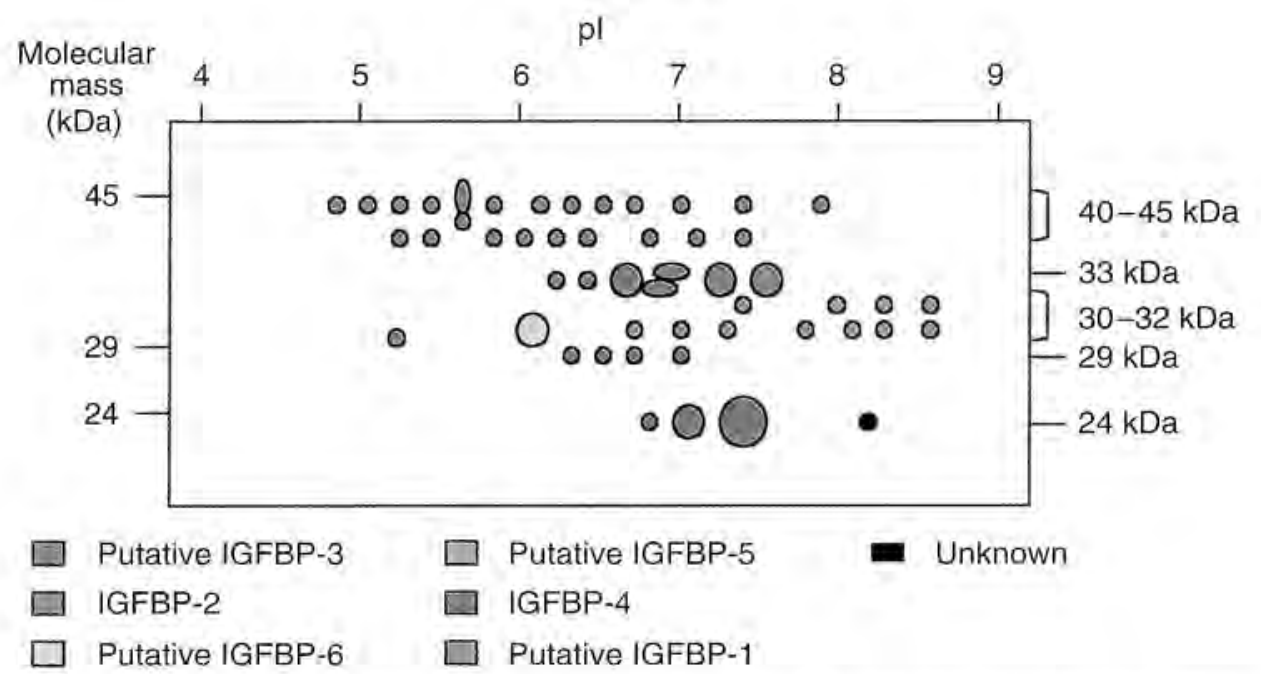

Fig. 6. Diagrammatic representation of insulin-like growth factor binding protein (IGFBP) profiles detected in bovine follicular fluid by two-dimensional electrophoresis and western blot ligand analysis. These results are from five oestrous-synchronized animals and include dominant and pooled subordinate follicles ( $1-4 \mathrm{~mm}$ in diameter). (Redrawn from Nicholas et al. 2002.)

Dephosphorylation of purified IGFBP-1 affects the affinity of IGFBP-1 for IGF-I and dephosphorylation of the IGFBPs in follicular fluid appears to decrease IGF-II binding to these proteins (Nicholas et al., 2002). However, the functional significance of deglycosylation is not clear. There are clearly gross changes in the IGFBP complement of follicular fluid during follicle development, although the effect of these post-translational modifications of the IGFBPs in follicular fluid remains to be determined.

One clear possibility lies in an altered susceptibility of these proteins to cleavage by IGFBP proteases, but this has not yet been demonstrated. Recently, the presence of IGF-dependent regulation of IGFBP-4 proteolytic degradation has been demonstrated in bovine follicular fluid (Mazerbourg et al., 2000). IGFBP-4 proteolytic activity was found to be highest in the dominant follicle (Rivera et al., 2001). This proteolytic action is inhibited by the IGFBP-3 and $-5 \mathrm{C}$-terminal domains, as well as being regulated by the heparin-binding domain. The protease that degrades IGFBP-4 has recently been shown to be the pregnancy-associated plasma protein A (PAPP-A; Monget et al., 2002). mRNA expression in bovine and ovine granulosa cells was maximal in preovulatory follicles and positively correlated with expression of both aromatase and LH receptors. However, it is not known whether PAPP-A expression is FSH

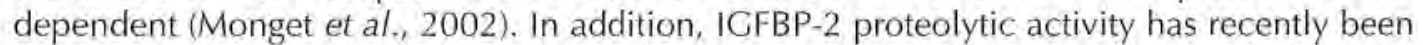
identified in bovine theca cell, but not granulosa cell, conditioned media. Furthermore, this activity was shown to be $\mathrm{Ca}^{2+}$-dependent and increased in the presence of $\mathrm{LH}$ (Nicholas el al., 2000).

Other locally produced growth factors include members of the TGF $\beta$ superfamily of ligands, which have been identified in mammalian ovaries. However, these factors are recognized by only a small number of receptors indicating that many ligands may share the same receptors, working through Smad signalling pathways. In the ovary, activin and TGF $\beta$ regulate steroidogenesis and proliferation in granulosa cells (Knight and Glister, 2001); however, BMP 
signalling pathways are less well understood. BMPs are involved in follicular maturation as indicated by the marked increase in ovulation rate in sheep with a BMP receptor mutation (Montgomery et al., 2001; Monget et al., 2002). BMP-2 has also been shown to enhance oestradiol production by ovine granulosa cells in vitro (Souza et al., 2002). Similarly, in bovine granulosa cells, BMP-4, -6 and -7 increased oestradiol, inhibin A, activin A and follistatin production when incubated individually, although no effects on $\mathrm{FSH}$-induced hormone secretion was detected (Glister et al., 2002). Overall, these results provide evidence for a functional role of BMPs, but the exact mechanisms and degree of redundancy need to be elucidated. In summary, there is a range of locally produced growth factors that have key roles in the selection of dominant follicles. The precise role of these factors and how they interact with gonadotrophins still remains to be elucidated.

\section{Follicle maturation, atresia and apoptosis}

Follicle development is tightly regulated by hormonal interactions. In monovulatory species, such as cattle, $99.9 \%$ of follicles are lost to atresia by normal physiological mechanisms at several key stages, namely the primordial (where they never develop), early antral (dependent upon FSH for survival (Markstrom et al., 2002)) and pre-ovulatory (during selection of the dominant follicle) stages. The survival of these follicles is directly dependent upon the interplay of the hormonal environment, which involves a range of factors, including IGFBPs, IGFBP proteases and MMPs, as discussed. It is possible that the physiological characteristics of subsequent atresia is determined simply through differences in size and differentiation state of the follicular cells and through the differentiation state of the oocyte. Atresia of unselected bovine follicles appears to be similar to atresia of dominant follicles, which is associated with a rapid decrease in the mRNA expression of both gonadotrophin receptors and the steroidogenic enzymes (Webb et al., 1999a).

In general, it is thought that once a signal is received, the onset of atresia is accompanied by the activation of the caspase pathway mediated via downstream effectors, such as caspases 3 and 7 (Johnson and Bridgham, 2002). This activation results in the loss of cell-cell contact, normal cell morphology and the cleavage of intracellular DNA according to general caspase mechanisms. In bovine follicles, apoptosis appears to be the mechanism that underlies atresia and this is linked to a shift in the ratio of anti-apoptotic (for example, $\mathrm{BCl}-2$ ) to pro-apoptotic protein (for example, Bax) expression. It appears that this shift is mediated primarily through the alteration in Bax (Yang and Rajamahendran, 2000).

\section{Extracellular matrix}

As the follicle consists of more than one type of cell, changes in granulosa, theca and stroma cells are bound to occur during atresia. Certainly, there is a loss of vasularization and, thus, oxygenation of the follicle. The extracellular matrix (ECM) also appears to be disrupted, which may be a consequence of loss of cellular deposition. ECM has an important role throughout follicular development (Rodgers and Irving-Rodgers, 2002) and both the granulosa and theca cells contribute to the deposition of the basement membrane, which separates the two types of cell, and serves to stabilize and protect the follicular environment. The basal lamina consists of several matrix components, the greatest proportion of which is laminin and colIagen IV, although perlecans and nidogen are expressed at different stages (Rodgers et al., 1999). Although maturational changes in the membrana granulosa are accompanied by changes in ECM, for example granulosa cells also secrete fibronectin (Skinner et al., 1985), 
(a)

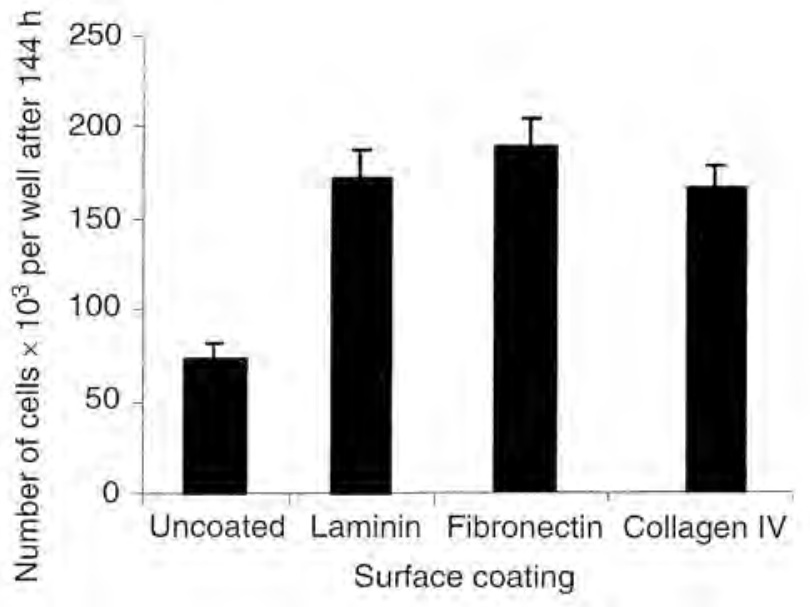

(b)

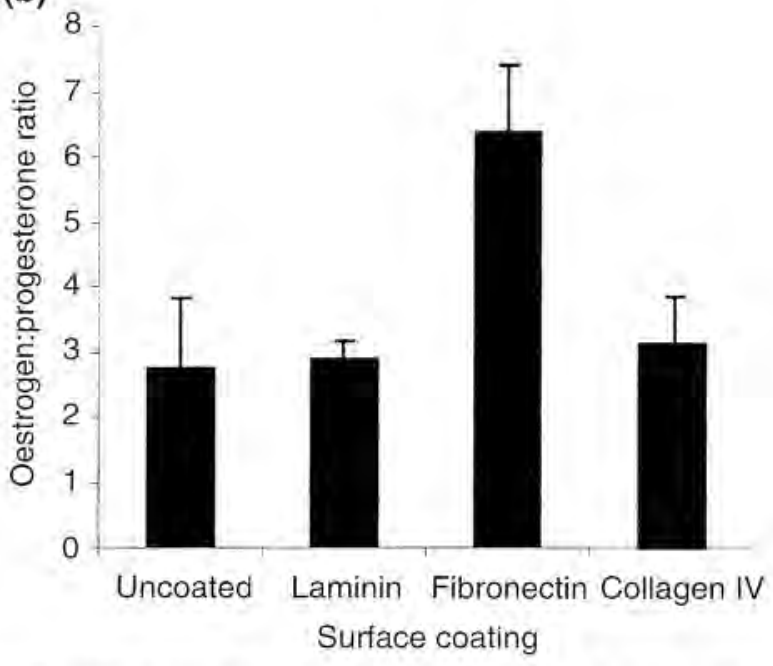

Fig. 7. Effect of different surface coatings of extracellular matrix on (a) granulosa cell proliferation and (b) steroidogenesis by bovine granulosa cells from medium-sized follicles (4-8 mm in diameter). Cells were cultured for $144 \mathrm{~h}$ as described by Gutierrez et al. (1997) and are the mean of three replicate cultures. (B. N. Nicholas, D. G. Armstrong and R. Webb, unpublished.)

Irving-Rodgers et al. (2002) concluded that the basal lamina is not degraded upon atresia indicating that it is unlikely that it is a key initiator of the events in early atresia.

Several of the IGFBPs, particularly IGFBP-3 and - 5 as both potentiate IGF activity, have affinity for selected ECM components including heparin (Mazerbourg et al., 2000). Granulosa cell proliferation and patterns of steroidogenesis in vitro change depending on the presence of ECM (Huet et al., 2001; Nicholas et al,, 2001). For example, culture plates coated with fibronectin had increased cell proliferation together with an increased oestradiol:progesterone ratio, unlike culture plates coated with laminin and collagen IV (Fig. 7). Therefore, it appears that 
IGFBP-2 can interact with components of the ECM in a gonadotrophic-dependent manner. This may be an important mechanism whereby granulosa cells can regulate their exposure to IGFs.

IGFBP-1 and - 2 also contain integrin recognition sequences (RGD binding sites), thereby potentiating their binding to integrins on the cell surface. Cleavage of these binding proteins by specific proteases during selection of the dominant follicle is thought to be the method by which free IGF is released into the follicular fluid to induce cellular proliferation. A reduction in these proteases is thought to lead to the build-up of considerable concentrations of IGFBPs resulting in the reduction of free IGF in follicular fluid and subsequent loss of growth followed by atresia (Monget et al., 2002). Although a purpose for the potential storage of IGF in the ECM remains obscure, some reports indicate that this provides a readily available store of IGFs for the follicular compartment, possibly by concentrating the IGF in specific areas close to cells. It has also been suggested that the transfer of IGFs to the ECM could serve to inactivate the free IGF load.

Other components of the extracellular space may influence follicular development, particularly the matrix metalloproteases (MMPS; Smith et al., 1999; Curry and Osteen, 2001), which enable the remodelling of the basement membrane by cleavage of specific membrane components. Ovine follicles contain both MMP-2 and -9, and intrafollicular concentrations of metalloproteases increase during atresia (Huet et al., 1998). Metalloproteases are involved during luteinization of the follicular contents after ovulation. It has been suggested that MMPs are responsible for the cleavage of the IGFBPs; however, other reports indicate that these proteases are serine proteases (Smith et al., 1999; Curry and Osteen, 2001). It has recently been shown in culture studies that bovine theca and granulosa cells can secrete gelatinolytic and caseinolytic MMPs in culture and that $\mathrm{LH}$ can stimulate production of gelatinase $\mathrm{A}$ from theca cells (M. T. Smith, C. G. Gutierrez, W. A. Ricke, D. G. Armstrong and R. Webb, unpublished). Therefore, it can be concluded that both the ECM and follicular proteases have a role in regulating the bioavailability of growth factors.

ECM products, such as fibronectin, may also influence the pattern of granulosa cell steroidogenesis (Huet et al., 2001; Fig. 7). Reports on the effects of laminin are conflicting as some indicate that culture of granulosa cells on laminin coated surfaces increases the synthesis of progesterone (Aten et al., 1995), whereas others imply the opposite (Bellego el al., 2002), although there was an inhibition of oestradiol synthesis indicating a role in luteinization. All reports indicate that laminin, which is expressed by theca cells (C. Allegrucci, J. Roger, M. G. Hunter, R. Webb and M. R. Luck, unpublished) and interacts with $\alpha 6 \beta 1$ integrin which is expressed in granulosa cells (Bellego et al, 2002), together with other ECM components, is capable of protecting granulosa cells from apoptosis. In addition, laminin may induce proliferation in these cells. Little information is available about the effect of matrix components on bovine follicular cells; however, matrix interactions may account, in part, for the altered synthesis of steroid hormones in co-culture experiments of theca and granulosa cells (Bosc and Nicolle, 1997). The ability of serum-free culture to maintain steroid production appears to relate to granulosa cell ultrastructure including cell-to-cell contact and the formation of gap junctions (Gutierrez et al, 1997). Overall, these results clearly demonstrate the importance of the structure-function relationships in follicle maturation and atresia.

\section{Conclusions}

Despite the recent progress in characterizing the temporal associations between changes in follicle dynamics and peripheral hormone concentrations, the precise mechanisms underlying 


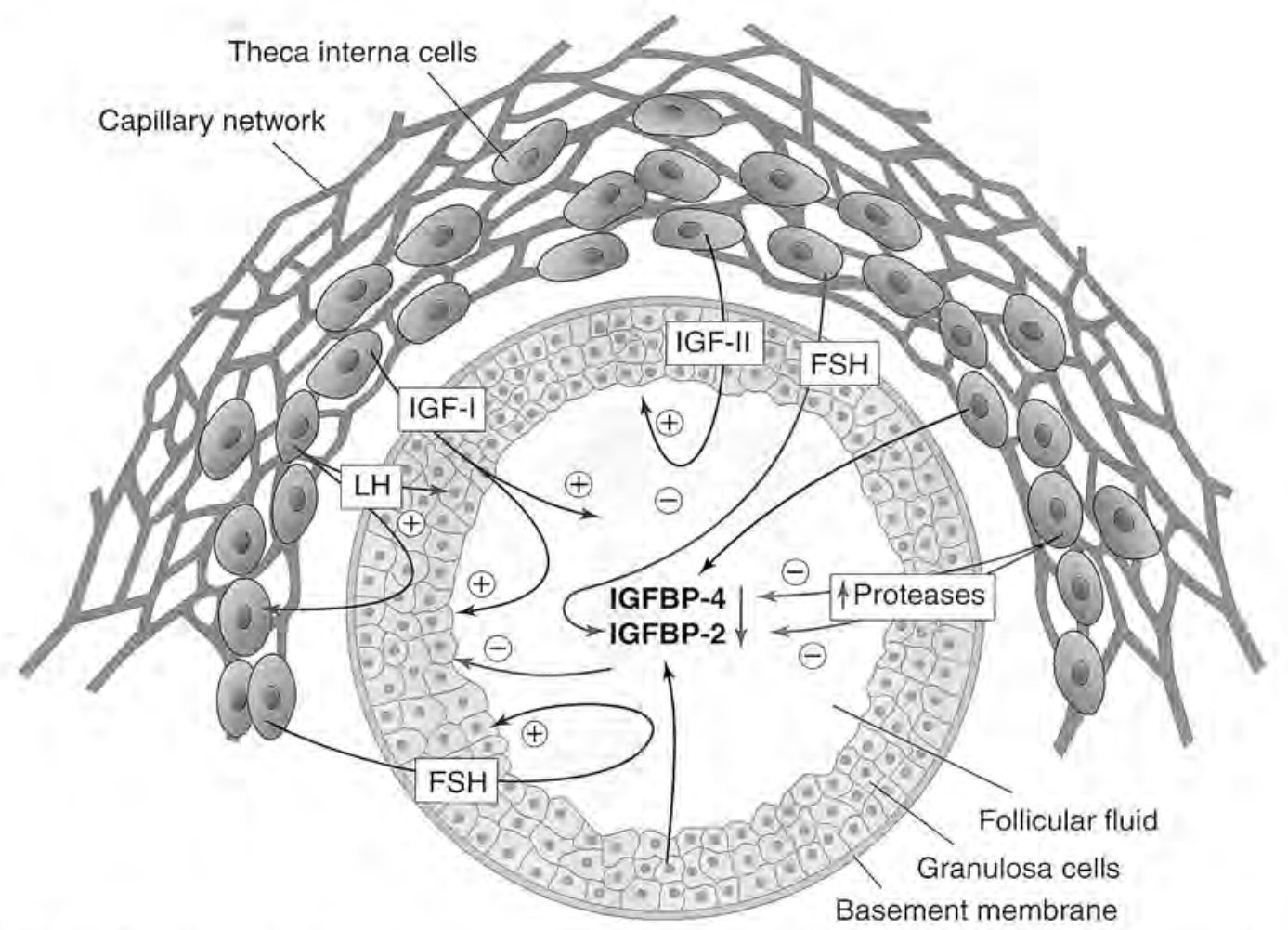

Fig. 8. The relationship between gonadotrophins and intrafollicular growth factors (in this example the insulin-like growth factor (IGF) system is depicted, although other growth factor systems, such as the transforming growth factor $\beta$ (TCF $\beta$ ) superfamily are also involved) in the selection and maintenance of the dominant follicle in cattle. FSH and LH are the primary stimulators of follicle growth, but interact with both extra- (IGF-I) and intra-follicular (IGF-II) growth factors to regulate follicle development. IGF ligand bioavailability is regulated by production of insulin-like growth factor binding protein 2 (IGFBP-2) from the granulosa cells and IGFBP-4 from the theca cells. Concentrations of IGFBPs are lower in dominant follicles due to reduced production of IGFBPs, partly through the inhibitory effect of FSH on gene expression, and increased thecal production of IGFBP proteases.

the follicular growth continuum remain to be elucidated. Follicle development is affected by the interplay between cell proliferation, cell differentiation and apoptosis. Gonadotrophins are the main driving force behind the survival signals for follicular cells; however, they do not always act directly, but ensure the correct growth factor environment. A range of paracrine factors (for example, IGFs; Fig. 8) can influence follicular cell growth and survival, whereas other factors simply promote follicular degeneration. Essentially, each follicle is on a knifeedge and either a greater or a lesser exposure and/or change in sensitivity to a range of factors, including gonadotrophins, can tip the balance between continued growth and differentiation or atresia.

In conclusion, the influence of growth factors on follicle survival is dependent on developmental stage (a process which is influenced by gonadotrophin status and, thus, steroidogenic state), growth factor load and differentiation state, including cell morphology, the ECM environment and the degree of vascularization of the follicle. 
The original work presented in the review was supported by BBSRC, Defra and SEERAD.

\section{References}

Adams GP (1999) Comparative patterns of follicle development and selection in ruminants fournal of $R e$ production and Fertility Supplement 54 17-32

Adashi EY, Resnick CE, Payne DW, Rosenfeld RG, Matsumoto T, Hunter MK, Gargosky SE, Zhou J and Bondy CA (1997) The mouse intraovarian insulin-like growth factor I system: departures from the rat paradigm Endocrinology $\mathbf{1 3 8} 3881$ 3890

Armstrong DG and Webb R (1997) Ovarian follicular dominance: the role of intraovarian growth factors and novel proteins Reviews of Reproduction 2139 146

Armstrong DG, Baxter G, Gutierrez CG, Hogg CO, Glazyrin AL, Campbell BK, Bramley TA and Webb R (1998) Insulin-like growth factor binding protein-2 and -4 mRNA expression in bovine ovarian follicles: effect of gonadotropins and developmental status Endocrinology 139 2146-2154

Armstrong DG, Gutierrez CG, Baxter G, Glazyrin AL, Mann GE, Woad KJ, Hogg CO and Webb R (2000) Expression of mRNA encoding IGF-I, IGF-II and type 1 IGF receptor in bovine ovarian follicles lournal of Endocrinology 165 101-113

Armstrong DG, Baxter G, Hogg CO and Woad KJ (2002) Insulin-like growth factor (IGF) system in the oocyte and somatic cells of bovine preantral follicles Reproduction $123789-797$

Aten RF, Kolodecik TR and Behrman HR (1995) A cell adhesion receptor antiserum abolishes, whereas laminin and fibronectin glycoprotein components of extracellular matrix promote, luteinization of cultured rat granulosa cells Endocrinology $1361753-$ 1758

Austin El, Mihm M, Evans ACO, Knight PG, Ireland JLH, Ireland JJ and Roche JF (2001) Alterations in intrafollicular regulatory factors and apoptosis during selection of follicles in the first follicular wave of the bovine estrous cycle Biology of Reproduction 64 839-848

Baird DT, Webb R, Campbell BK, Harkness LM and Gosden RG (1999) Long term ovarian function in sheep following ovariectomy and transplantation of autographs stores at $-196^{\circ} \mathrm{C}$ Endocrinology 140125 138

Bao B and Garverick HA (1998) Expression of steroidogenic enzyme and gonadotropin receptor genes in bovine follicles during ovarian follicular waves: a review Journal of Animal Science 76 19031921

Bellego FL, Pisselet $C$, Huet $C$, Monget $P$ and Monniaux D (2002) Laminin- $\alpha 6 \beta 1$ integrin interaction enhances survival and proliferation and modulates ster- oidogenesis of ovine granulosa cells Journal of Endocrinology 172 45-59

Bleach ECL, Glencross RG, Feist SA, Groome NP and Knight PG (2001) Plasma inhibin A in heifers: relationship with follicle dynamics, gonadotropins, and steroids during the estrous cycle and after treatment with bovine follicle fluid Biology of Reproduction 64 743-752

Bosc MJ and Nicolle A (1997) Steroid production by co-cultures of granulosa cells with inner and outer theca cells in preovulatory follicles of gonadotropin stimulated calves Journal of Steroid Biochemistry and Molecular Biology 62 213-221

Braw-Tal R and Yossefi S (1997) Studies in vivo and in vitro on the initiation of follicle growth in the bovine ovary Journal Reproduction and Fertility 109 165-171

Campbell BK and Baird DT (2001) Inhibin A is a follicle stimulating hormone-responsive marker of granulosa cell differentiation, which has both autocrine and paracrine actions in sheep Journal of Endocrinology $169333-345$

Campbell BK and Scaramuzzi RJ (1995) Effect of acute immunoneutralization of inhibin in ewes during the late luteal phase of the aestrous cycle on ovarian hormone secretion and follicular development during the subsequent follicular phase Journal of Reproduction and Fertility $104337-345$

Campbell BK, Scaramuzzi RJ and Webb R (1995) Control of antral follicle development and selection in sheep and cattle Journal of Reproduction and Fertility Supplement $49335-350$

Campbell BK, Telfer EE, Webb R and Baird DT (2000) Ovarian autografts in sheep as a model for studying folliculogenesis Molecular and Cell Endocrinology $163137-139$

Curry TE and Osteen KG (2001) Cyclic changes in the matrix metalloproteinase system in the ovary and uterus Biology of Reproduction 64 1285-1296

Echternkamp SE, Howard RJ, Roberts AJ, Grizzle J and Wise T (1994) Relationships among concentrations of steroids, insulin-like growth factor I and insulinlike growth factor binding proteins in ovarian follicular fluid of beef cattle Biology of Reproduction 51 971-981

Elvin JA and Matzuk MM (1998) Mouse models of ovarian failure Reviews of Reproduction 3 183-195

Fortune IE (1994) Ovarian follicular growth and development in mammals Biology of Reproduction $\mathbf{5 0}$ 225-232

Fortune JE, Cushman RA, Wahl CM and Kito WS (2000) The primordial to primary follicle transition Molecular and Cellular Endocrinology $16353-60$ 
Fortune JE, Rivera GM, Evans ACO and Turzillo AM (2001) Differentiation of dominant versus subordinate follicles in cattle Biology of Reproduction $\mathbf{6 5}$ 648-654

Garverick HA, Baxter G, Gong J, Armstrong DG, Campbell BK, Gutierrez CG and Webb R (2002) Regulation of expression of ovarian mRNA encoding steroidogenic enzymes and gonadotrophin receptors by $\mathrm{FSH}$ and $\mathrm{GH}$ in hypogonadotrophic cattle Reproduction $123651-661$

Gibbons JR, Wiltbank MC and Ginther OJ (1997) Functional inter-relationships between follicles greater than $4 \mathrm{~mm}$ and follicle-stimulating hormone surge in heifers Biology of Reproduction $\mathbf{5 7}$ 10661073

Ginther OJ, Bergfelt DR, Kulick LJ and Kot K (2000) Selection of the dominant follicle in cattle: role of twoway functional coupling between follicle-stimulating hormone and the follicles Biology of Reproduction $62920-927$

Ginther OJ, Beg MA, Bergfelt DR, Donadeu FX and Kot K (2001) Follicle selection in monovular species Biology of Reproduction 65 638-647

Glister C, Morgan AL and Knight PG (2002) Bone morphogenic protein (BMP)-mediated modification of steroid and inhibin-related peptide secretion by non-luteinized bovine granulosa cells Reproduction Abstract Series 28 Abstract 70

Gong JG, Bramley TA, Gutierrez CG, Peters AR and Webb R (1995) Effects of chronic treatment with a gonadotrophin-releasing hormone agonist on peripheral concentrations of $\mathrm{FSH}$ and $\mathrm{LH}$, and ovarian function in heifers Journal of Reproduction and Fertility $105263-270$

Gong JG, Campbell BK, Bramley TA, Gutierrez CG, Peters AR and Webb R (1996a) Suppression in the secretion of follicle-stimulating hormone and luteinizing hormone, and ovarian follicle development in heifers continuously infused with a gonadotropinreleasing hormone agonist Biology of Reproduction 55 68-74

Gong JG, Campbell BK and Webb R (1996b) Effects of infusion with $\mathrm{FSH}$, with or without $\mathrm{LH}$, on ovarian follicle growth and development in GnRH agonisttreated heifers Journal of Reproduction and Fertility Abstract Series 18 Abstract 9

Gosden RC, Baird DT, Wade JC and Webb R (1994) Restoration of fertility in oophorectomised sheep by ovarian autogralts stored at $-196^{\circ} \mathrm{C}$ Human Reproduction 9 597-603

Gutierrez CG, Glazyrin AL, Robertson GW, Campbell BK, Gong JG, Bramley TA and Webb R (1997) Ultrastructural characteristics of bovine granulosa cells associated with maintenance of oestradiol production in vitro. Molecular and Cellular Endocrinology 134 $51-58$

Gutierrez CG, Ralph JH, Telfer EE, Wilmut I and Webb R (2000) Growth and antrum formation of bovine antral follicles in long-term culture in vitro. Biology of Reproduction 62 1322-1328

Huet C, Monget P, Pisselet C, Hennequet C, Locatelli A and Monniaux D (1998) Chronology of events accompanying follicular atresia in hypophysectomized ewes. Changes in levels of steroidogenic enzymes, connexin 43, insulin-like growth factor $11 /$ mannose 6 phosphate receptor, extracellular matrix components and matrix metalloproteinases Biology of Reproduction 58 175-185

Huet C, Pisselet C, Mandon-Pepin B, Monget P and Monniaux D (2001) Extracellular matrix regulates ovine granulosa cell survival, proliferation and steroidogenesis: relationships between cell shape and function Journal of Endocrinology $169347-$ 360

Irving-Rodgers HF, Mussard ML, Kinder JE and Rodgers RJ (2002) Composition and morphology of the follicular basal lamina during atresia of bovine antral follicles Reproduction 123 97-106

Johnson AL and Bridgham JT (2002) Caspase-mediated apoptosis in the vertebrate ovary Reproduction 124 19-27

Juengel JL, Sawyer HR, Smith PR, Quirke LD, Heath DA, Lun S, Wakefield I and McNatty KP (2002) Origins of follicular cells and ontogeny of steroidogenesis in ovine fetal ovaries Molecular and Cellular Endocrinology 191 1-10

Knight PG and Glister C (2001) Potential local regulatory functions of inhibins, activins and follistatin in the ovary Reproduction 121 503-512

Kulick LJ, Kot K, Wiltbank MC and Ginther OJ (1999) Follicular and hormonal dynamics during the first follicular wave in heifers Theriogenology 52 913921

Leeuwenberg BR, Hurst PR and McNafty KP (1995) Expression of $1 \mathrm{GF}-1$ mRNA in the ovine ovary Journal of Molecular Endocrinology 15 251-258

McCaffery FH, Leask R, Riley SC and Telfer EE (2000) Culture of bovine preantral follicles in a serum-free system: markers for assessment of growth and devel opment Biology of Reproduction $63267-273$

McNatty KP, Heath DA, Lindy F, Fidler AE, Quirke L, O'Connell A, Smith P, Groome $N$ and Tisdall DJ (1999) Control of early ovarian follicular development Journal of Reproduction and Fertility Supplement 54 3-16

Markstrom E, Svensson EC, Shao R, Svanberg B and Billig $\mathbf{H}$ (2002) Survival factors regulating ovarian apoptosis - dependence on follicle differentiation Reproduction $12323-30$

Mazerbourg S, Zapf J, Bar RS, Brigstock DR and Monget $\mathbf{P}$ (2000) Insulin-like growth factor (IGF)binding protein-4 proteolytic degradation in bovine, equine, and porcine preovulatory follicles: regulation by IGFs and heparin-binding domaincontaining peptides Biology of Reproduction 63 $390-400$ 
Mihm M, Good TEM, Ireland JLH, Ireland JJ, Knight $\mathbf{P}$ and Roche I (1997) Decline in serum folliclestimulating hormone concentrations alters key intrafollicular growth factors involved in selection of the dominant follicle in heifers Biology of Reproduction 57 1328-1337

Mihm M, Austin EJ, Good TEM, Ireland JLH, Knight PG, Roche JF and Ireland J] (2000) Identification of potential intrafollicular factors involved in selection of dominant follicles in heifers Biology of Reproduc tion 63 811-819

Monget P, Fabre S, Mulsant P, Lecerf F, Elsen IM, Mazerbourg S, Pisselet C and Monniaux D (2002) Regulation of ovarian folliculogenesis by IGF and BMP system in domestic animals Domestic Animal Endocrinology 23 139-154

Montgomery GW, Galloway SM, Davis GH and McNatty KP (2001) Genes controlling ovulation rate in sheep Reproduction 121 843-852

Nicholas BL, Webb R and Armstrong DG (2000) Chàracterization of insulin-like growth factor binding protein-2 (IGFBP-2) prolease activity in bovine theca cell conditioned media lournal of Reproduction Abstract Series 2552

Nicholas B, Webb R, Hogg C, Baxter G, Goddard C and Armstrong D (2001) Differentiative effects of IGF system components on bovine follicular cells Biology of Reproduction Supplement $64 \mathrm{Abstract}$ 150

Nicholas B, Scougall RK, Armstrong DG and Webb R (2002) Changes in insulin-like growth factor binding protein (IGFBP) isoforms during bovine follicular development Reproduction 124 439-446

Perks CM, Denning-Kendall PA, Gilmour RS and Wathes DC (1995) Localization of messenger ribonucleic acids for insulin-like growth factor 1 (IGF-1), IGF-II and the type 1 IGF receptor in the ovine ovary throughout the estrous cycle Journal of Endocrinology $1365266-5273$

Perks CM, Peters AR and Wathes DC (1999) Follicular and luteal expression of insulin-like growth factor I and II and the type I ICF receptor in the bovine ovary Journal of Reproduction and Fertility $116157-$ 165

Rivera GM, Chandrasekher YA, Evans ACO, Giudice LC and Fortune JE (2001) A potential role for insulin-like growth factor binding protein-4 proteolysis in the establishment of ovarian follicular dominance in cattle Biology of Reproduction 65 102-111

Rodgers RJ and Irving-Rodgers HF (2002) Extracellular matrix of the bovine ovarian membrana granulosa Molecular and Cellular Endocrinology 191 57-64

Rodgers RJ, van Wezel IL, Irving-Rodgers HF, Lavranos TC, Irvine CM and Krupa M (1999) Roles of extracellular matrix in follicular development journal of Reproduction and Fertility Supplement 54 343352
Silva KM and Price CA (2001) Effect of folliclestimulating hormone on steroid secretion and messenger ribonucleic acids encoding cytochromes P450 aromatase and cholesterol side-chain cleavage as bovine granulosa cells in vitro. Biology of Reproduction 62 186-191

Skinner MK, McKeracher HL and Dorrington JH (1985) Fibronectin as a marker of granulosa cell cytodifferentiation Endocrinology 117 886-892

Skyer DM, Gaverick HA and Youngquist RS (1987) Populations and steroidogenesis in vitro of follicles from three different days of the bovine estrous cycle Joumal of Animal Science 64 1710-1716

Smith MF, McIntush EW, Ricke WA, Kojima FN and Smith GW (1999) Regulation of ovarian extracellular matrix remodelling by metalloproteinases and their lissue inhibitors: effects on follicular development, ovulation and luteal function Journal of Reproduction and Fertility Supplement $\mathbf{5 4} 367-$ 381

Smitz JE and Cortvindt RG (2002) The earliest stages of folliculogenesis in vitro Reproduction $123185-$ 202

Souza CJH, Campbell BK, MCNeilly AS and Baird DT (2002) Effect of bone morphogenetic protein 2 (BMP2) on oestradiol and inhibin A production by sheep granulosa cells, and localization of BMP receptors in the ovary by immunohistochemistry Reproduction 123 363-369

Spicer LJ and Echternkamp SE (1995) The ovarian insulin and insulin-like growth factor system with an emphasis on domestic animals Domestic Animal En. docrinology 12 223-245

Spicer LJ, Alpizar E and Echternkamp SE (1993) Effects of insulin, insulin-like growth factor 1 , and gonadotropins on bovine granulosa cell proliferation, progesterone production, estradiol production and (or) insulin-like growth factor 1 production in vitro. Journal of Animal Science 71 1232-1241

Thomas FH, Leask R, Srsen V, Riley SC, Spears N and Telfer EE (2001) Effect of ascorbic acid on health and morphology of bovine preantral follicles during long-term cultures Reproduction 122 487-495

Wandji SA, Gadsby IE, Simmen FA, Barber JA and Hammond IM (2000) Porcine ovarian cells express messenger ribonucleic acid for the acid-labile subunit and insulin-like growth factor binding protein-3 during follicular and luteal phases of the estrous cycle Endocrinology 141 2638-2647

Webb R and Morris BA (1988) The effect of steroid and inhibin immunity on FSH and ovulation Proceedings of the 11th International Congress on Animal Reproduction and Al 3 183-191

Webb R, Campbell BK, Garverick HA, Gong IG, Gutierrez CG and Armstrong DG (1999a) Molecular mechanisms regulating follicular recruitment and selection Journal of Reproduction and Fertility Supplement $5433-48$ 
Webb R, Gosden RG, Telfer EE and Moor RM (1999b) Factors affecting folliculogenesis in ruminants $A n$ imal Science 68 2.57-284

Yang MY and Rajamahendran R (2000) Involvement of apoptosis in the atresia of nonovulatory dominant follicle during the bovine estrous cycle Biology of Reproduction 63 1313-1321
Yuan W, Bao B, Garverick HA, Youngquist RS and Lucy MC (1998) Follicular dominance in cattle is associated with divergent patterns of ovarian gene expression for insulin-like growth factor (IGF) -1, IGF-1I and IGF binding protein-2 in dominant and subordinate follicles Domestic Anima! Endocrinology 15 5563 